\title{
ANTIBACTERIAL ACTIVITIES TEST OF COMBINATION OF ETHANOLIC EXTRACT OF BETEL LEAVES (Piper betle L.) AND BASIL LEAVES (Ocimum basilicum L.) AGAINST Staphylococcus aureus
}

\author{
Junie Suriawati, Patimah, dan Siti Rahayu Rachmawati \\ Jurusan Analisa Farmasi dan Makanan, Politeknik Kesehatan Kemenkes Jakarta II, \\ Jl. Raya Ragunan No. 29 C, Pasar Minggu, Jakarta Selatan, 12540 \\ E-mail: juniesuriawati@yahoo.co.id
}

\begin{abstract}
Betel leaf extract and basil leaf extract contain phenol compounds, safonin, flavonoids, tannins, and essential oils that act as antibacterials. Skin is very susceptible to infection or other skin diseases one of which is caused by Staphylococcus aureus bacteria. This research needs to be done to test the antibacterial activity of ethanol extract of green betel leaf, basil leaf and combination of both extracts to S. aureus. The process of extraction of betel leaf and basil leaves was done with $96 \%$ ethanol solvent using maceration method. The combinations used in the sample solution were the concentration of ethanol extract of green betel leaf $(0 \%, 15 \%, 30 \%, 45 \%, 60 \%, 75 \%)$ and basil leaf extract $(0 \%, 15 \%$, $30 \%, 45 \%, 60 \%, 75 \%)$. Furthermore, the antibacterial activity was tested for S. aureus with well diffusion method. The data obtained were tested statistically using Anova and Duncan's advanced test. The result of statistical analysis showed difference of drag zone $(\mathrm{p}<0,05)$ between various concentration of ethanol extract of green betel leaf, basil leaf and combination of both extracts to S. aureus. The smallest resin zone of ethanol extract of betel leaf and ethanol extract of basil leaves is at $0 \%$ concentration (S0 and K0) and highest at 75\% concentration (S5 and K5). While the smallest zone of inhibition for the combination of ethanol extract of betel leaf and ethanol extract of basil leaves at concentration S0K0, S0K1 and S0K2 is $0 \mathrm{~mm}$ and highest at S5K5 concentration is $31,3 \mathrm{~mm}$. The higher concentration of betel leaf extract, basil leaf extract and the combination of the two extracts, the inhibition of diameter zone will be better. It can be concluded that the combination of betel leaf extract and basil leaf extract has the ability to inhibit the growth of $S$. aureus better than single extract.
\end{abstract}

Keywords: antibacterial, betel, basil, combination, S. aureus

\section{UJI AKTIVITAS ANTIBAKTERI KOMBINASI EKSTRAK ETANOL DAUN SIRIH (Piper betle L.) DAN DAUN KEMANGI (Ocimum basilicum L.) TERHADAP Staphylococcus aureus}

\begin{abstract}
ABSTRAK
Ekstrak daun sirih dan ekstrak daun kemangi memiliki kandungan senyawa fenol, safonin, flavonoid, tanin, dan minyak atsiri yang berfungsi sebagai antibakteri. Kulit sangat rentan terkena infeksi ataupun penyakit kulit lain yang salah satunya disebabkan oleh bakteri Staphylococcus aureus. Penelitian ini perlu dilakukan untuk menguji aktivitas antibakteri ekstrak etanol daun sirih hijau, daun kemangi dan kombinasi kedua ekstrak terhadap $S$.aureus. Proses ekstraksi daun sirih dan daun kemangi dilakukan dengan pelarut etanol $96 \%$ menggunakan metode maserasi. Kombinasi yang digunakan dalam larutan sampel adalah konsentrasi ekstrak etanol daun sirih hijau $(0 \%, 15 \%, 30 \%, 45 \%, 60 \%, 75 \%)$ dan ekstrak daun kemangi $(0 \%, 15 \%, 30 \%, 45 \%, 60 \%, 75 \%)$. Selanjutnya dilakukan uji aktivitas antibakteri terhadap S. aureus dengan metode difusi sumur. Data yang diperoleh diuji secara statistik menggunakan Anova dan uji lanjut Duncan. Hasil analisis statistik menunjukkan perbedaan zona hambat $(\mathrm{p}<0,05)$ antara berbagai konsentrasi ekstrak etanol daun sirih hijau, daun kemangi dan kombinasi kedua ekstrak terhadap S. aureus. Zona hambat terkecil pada ekstrak etanol daun sirih dan ekstrak etanol daun kemangi yaitu pada konsentrasi 0\% (S0 dan K0) dan tertinggi pada konsentrasi 75\% (S5 dan K5). Sedangkan zona hambat terkecil untuk kombinasi ekstrak etanol daun sirih dan ekstrak etanol daun kemangi pada konsentrasi S0K0, S0K1 dan S0K2 sebesar 0 mm dan tertinggi pada konsentrasi S5K5 sebesar 31,3 $\mathrm{mm}$. Semakin tinggi konsentrasi ekstrak daun sirih, ekstrak daun kemangi dan kombinasi kedua ekstrak maka diameter zona hambat akan semakin besar. Dapat disimpulkan bahwa kombinasi ekstrak daun sirih dan ekstrak daun kemangi memiliki kemampuan dalam menghambat pertumbuhan $S$. aureus lebih baik dibandingkan ekstrak tunggal.
\end{abstract}

Kata kunci: antibakteri, sirih, kemangi, kombinasi, S. aureus 


\section{PENDAHULUAN}

Kulit sangat rentan terkena infeksi ataupun penyakit kulit lain yang salah satunya disebabkan oleh bakteri Staphylococcus aureus (S. aureus). Bakteri ini dapat masuk ke dalam kulit melalui folikel rambut, kelenjar sebasea, luka atau lecet pada kulit. S. aureus merupakan penyebab terjadinya berbagai infeksi epidermal dan subkutan seperti piogenik, lesi supuratif, bisul, infeksi pneumonia, dan luka (1). Bakteri S. aureus bertanggung jawab atas $80 \%$ penyakit supuratif, dengan permukaan kulit sebagai habitat alaminya (2). Penyebaran bakteri $S$. aureus paling sering ditular dari tangan ke tangan (3).

Penyebab bakteri patogen melalui tangan dapat dicegah dengan mencuci tangan. Cuci tangan dapat mencegah lebih dari satu juta kematian pertahun akibat penyakit diare, sedangkan mencuci tangan dengan sabun dapat menurunkan diare hingga $47 \%$ (4). Selain itu cuci tangan dengan menggunakan antiseptik dapat mengurangi jumlah bakteri dan antiseptik etanol menunjukkan hasil yang lebih baik dibandingkan dengan antiseptik irgasan atau sabun triklosan (5). Meskipun demikian, penggunaan antiseptik kimia secara terus menerus dan berlebihan dikhawatirkan dapat menimbulkan kerusakan pada jaringan tangan. Oleh karena itu perlu dicari alternatif pengganti antiseptik kimia berupa bahan-bahan alami.

Tanaman dengan bahan antiseptik alami yang biasa digunakan untuk perawatan kesehatan dan pencegahan penyakit mulai dikembangkan, diantaranya daun sirih dan daun kemangi. Ekstrak daun sirih hijau mampu membunuh bakteri $S$. aureus karena didalamnya terkandung bahan kimia yang mempunyai aktivitas antibakteri yaitu minyak atsiri, tanin, flavonoid, dan saponin (6).

Kandungan minyak atsiri dalam daun sirih hijau adalah $30 \%$ fenol dan beberapa derivatnya yang sebagian besar terdiri dari Chavicol paraallyphenol dari Chevica (7). Pemberian ekstrak daun sirih (Piper betle L.) dapat menghambat $S$. aureus isolat dari penderita faringitis (8). Sedangkan ekstrak etilasetat daun sirih (Piper betle L.) dapat menghambat Staphylococcus epidermidis pada konsentrasi 3\% dan 5\% dengan daya hambat 9,8 mm dan $15 \mathrm{~mm}$ (7).

Daun kemangi juga memiliki aktivitas antiseptik sama seperti daun sirih karena kandungan utamanya 
adalah linalool $(56,7 \%)$ yang berfungsi sebagai antibakteri (9). Aktivitas antibakteri ekstrak etanol daun kemangi (Ocimum sanctum L.) dapat menghambat pertumbuhan Escherichia coli dan S. aureus (10). Mekanisme antiseptik pada daun sirih dan daun kemangi disebabkan karena keduanya mengandung fenol dan senyawa turunannya yang dapat mendenaturasi protein bakteri (11).

Kombinasi ekstrak dari beberapa tanaman yang disatukan memiliki daya hambat antibakteri yang lebih besar dibandingkan dengan ekstrak tanaman tunggal (1). Penelitian kombinasi ekstrak daun sirih dan daun lidah buaya menunjukkan adanya interaksi antar konsentrasi dan jenis ekstrak terhadap daya hambat $S$. aureus. Semakin tinggi konsentrasi interaksi yang diberikan semakin besar daya hambat yang terbentuk. Diameter daya hambat terbesar pada perlakuan daun sirih dan daun lidah buaya masing masing dengan konsentrasi $75 \%$, yaitu $25 \mathrm{~mm}$ pada $S$. aureus. Penelitian ini bertujuan untuk mengetahui efektivitas antibakteri dari kombinasi ekstrak etanol daun sirih Piper betle L.) dan ekstrak etanol daun kemangi (Ocimum basilicum L.) terhadap S. aureus (12).

\section{METODE PENELITIAN}

\section{Alat dan Bahan}

Alat-alat penelitian yang digunakan adalah autoklaf (Hirayama model HL 36 AE), inkubator (Memmert), oven (Heraeus Instruments), mikroskop (Olympus), timbangan analitik (Ohaus), vortex (Scientific), cork borer, jangka sorong, tabung reaksi, cawan petri, labu Erlenmeyer, gelas ukur, pembakar spiritus, mikropipet (Gilson), tip kuning, tip biru.

Bahan yang digunakan adalah simplisia daun sirih (Piper betle L.) dan simplisia daun kemangi (Ocimum basilicum L.), etanol 96\% (Merck), Nutrien agar (NA) (Merck), Brain Heart Infusion Broth (BIHB) (Merck), cakram antibiotika (Sigma): Cloramphenicol $30 \mu \mathrm{g}$ dan tetracycline $30 \mu \mathrm{g}$, Dimethil Sulfoxide (DMSO), Staphylococcus aureus InaCC B286.

\section{Persiapan dan Ekstraksi Sampel}

Sampel daun sirih (Piper betle L.) dan daun kemangi (Ocimum basilicum L.) diperoleh dari Balai Penelitian Tanaman Rempah dan Obat (Balitro) di Bogor. Sampel daun dipilih menggunakan metode purposive sampling. Tanaman sirih dan tanaman 
kemangi dideterminasi di LIPI Bogor, tujuannya untuk memastikan kebenaran tanaman dan mengetahui jenis tanaman yang akan digunakan dalam penelitian.

Simplisia daun sirih dan daun kemangi dari Balitro diekstraksi dengan cara $1000 \mathrm{~g}$ serbuk daun sirih direndam dengan $2500 \mathrm{~mL}$ alkohol 96\%, dikocok selama 30 menit lalu dibiarkan selama 24 jam sampai dengan mengendap. Hasil perendaman disaring dan kemudian filtrat hasil perendaman dievaporasi menggunakan rotary evaporator, pemanasan water bath (30$\left.40^{\circ} \mathrm{C}\right)$. Hasil ekstrak dimasukkan ke dalam botol kaca coklat dan disimpan dalam kulkas suhu $10^{\circ} \mathrm{C}$. Ekstrak yang diperoleh dijadikan sebagai larutan stok. Kemudian dari larutan stok dibuat pengenceran dengan DMSO untuk memperoleh konsentrasi 75\%, 60\%, $45 \%, 30 \%$, dan $15 \%$.

\section{Uji Aktivitas Antibakteri}

\section{Persiapan kultur bakteri uji Staphylococcus aureus.}

Bakteri diinokulasikan ke media BHIB, diinkubasi pada suhu $37^{\circ} \mathrm{C}$ selama 24 jam. Bakteri yang tumbuh diencerkan dengan $\mathrm{NaCl}$ 0,85\%, dan kekeruhannya disesuaikan dengan Mc Farland 0,5 (1,5 x $\left.10^{8} \mathrm{cfu} / \mathrm{mL}\right)$.

\section{Persiapan bakteri uji untuk difusi} sumur. Sebanyak 0,2 mL inokulum $S$. aureus yang jumlahnya setara dengan Mc Farland 0,5 diinokulasikan masingmasing ke dalam $20 \mathrm{~mL}$ media NA yang suhunya $\pm 45^{\circ} \mathrm{C}$, kemudian dihomogenkan. Media NA yang telah mengandung bakteri uji dituang ke dalam cawan petri steril. Setelah media mengeras dibuat sumur dengan menggunakan cork borer diameter 7 $\mathrm{mm}$. Sebanyak $50 \mu \mathrm{l}$ dari masingmasing konsentrasi ekstrak daun sirih, ekstrak daun kemangi, serta kombinasi konsentrasi ekstrak daun sirih dan ekstrak daun kemangi diisikan ke dalam sumur pada media agar dan sebagai pembanding digunakan antibiotik Cloramphenicol $30 \mu \mathrm{g}$ dan tetracycline $30 \mu \mathrm{g}$ (kontrol positif) serta DMSO (kontrol negatif). Media tersebut didiamkan selama 15-20 menit pada $27^{0} \quad \mathrm{C}$, diharapkan sampel dan pembanding tersebut meresap ke dalam media agar. Selanjutnya diinkubasi pada suhu $37^{0}$ C selama 24-48 jam. Pengamatan dilakukan dengan mengukur zona penghambatan yang ditandai dengan area bening disekeliling sumur. Pengukuran dilakukan dalam satuan milimeter $(\mathrm{mm})$. Besarnya 
diameter zona penghambatan merupakan nilai pengurangan diameter zona penghambatan bakteri uji dengan diameter zona penghambatan kontrol (pelarut). Pengulangan dilakukan sebanyak 3 (tiga) kali (13).

\section{Analisis Data}

Penelitian ini merupakan penelitian eksperimental. Data yang diperoleh dianalisis dengan ANOVA satu arah dan jika terdapat perbedaan dilanjutkan uji Duncan dengan taraf kepercayaan $95 \%$ untuk mengetahui perbedaan antara kelompok perlakuan satu dengan yang lainnya.

\section{HASIL DAN PEMBAHASAN}

Sampel segar daun sirih hijau dan daun kemangi diidentifikasi di Lembaga Ilmu Pengetahuan Indonesia (LIPI) sebagai tanaman dengan jenis Piper betle L. suku Piperaceae dan Ocimum americanum L. suku Lamiaceae.
Kemudian dibuat simplisia kering daun sirih hijau dan daun kemangi di Balai Penelitian Tanaman Rempah dan Obat (BALITRO) Bogor, Jawa Barat.

Proses pengambilan zat aktif yang terkandung dalam daun sirih dan daun kemangi dilakukan dengan cara maserasi menggunakan Etanol 96\% sebagai larutan penyari. Etanol adalah pelarut organik yang dapat menarik sebagian besar senyawa-senyawa bioaktif yang terdapat dalam simplisia dan kepolarannya meningkat dengan meningkatnya kandungan air (14).

Maserat yang didapatkan dari proses maserasi, dipekatkan dengan rotary evaporator sehingga diperoleh ekstrak kental etanol daun sirih dan ekstrak kental etanol daun kemangi dengan warna hijau. Dari 1000 g simplisia daun sirih dan daun kemangi yang diekstraksi menggunakan etanol 96\% diperoleh rendeman masingmasing sebanyak $10,3 \%$ dan $16,9 \%$

Tabel 1. Rendeman ekstrak etanol daun sirih dan daun kemang

\begin{tabular}{lccc}
\hline Jenis ekstrak & $\begin{array}{c}\text { Bobot } \\
\text { simplisia } \\
(\mathrm{g})\end{array}$ & $\begin{array}{c}\text { Bobot } \\
\text { ekstrak } \\
(\mathrm{g})\end{array}$ & $\begin{array}{c}\text { Rendeman } \\
(\%)\end{array}$ \\
\hline Daun sirih & 1000 & 103 & 10,3 \\
Daun kemangi & 1000 & 169 & 16,9 \\
\hline
\end{tabular}


seperti terlihat padat Tabel 1 .

Potensi aktivitas antibakteri ekstrak etanol daun sirih, ekstrak etanol daun kemangi, dan kombinasinya terhadap bakteri $S$. aureus dapat dilakukan dengan uji aktivitas antibakteri. Pengujian dilakukan menggunakan metode difusi sumur dan hasil ditandai dengan adanya daerah bening (zona hambat) disekitar lubang pada sumur agar di cawan petri yang mengandung berbagai konsentrasi larutan ekstrak. Metode difusi agar dipilih karena paling sensitif untuk menilai potensi antibakteri dari ekstrak kasar bahan alam (15).

Diperoleh hasil pengujian dengan mengukur zona hambat yang terbentuk dari ekstrak etanol daun sirih dan ekstrak etanol daun kemangi terhadap $S$. aureus yang dapat dilihat pada Gambar 1. Gambar mempelihatkan semakin tinggi konsentrasi ekstrak etanol daun sirih dan ekstrak etanol kemangi sebagai zat antibakteri maka semakin besar zona hambat yang terbentuk. Hal ini dapat disebabkan oleh adanya kandungan senyawa metabolit sekunder yang terdapat di dalam ekstrak. Senyawa metabolit sekunder ekstrak etanol daun sirih dan ekstrak etanol daun kemangi dapat berupa flavonoid dan tanin. Hal ini dinyatakan juga oleh (16) bahwa hasil metabolit sekunder yang dihasilkan dengan menggunakan pelarut polar seperti etanol, metanol, etilasetat

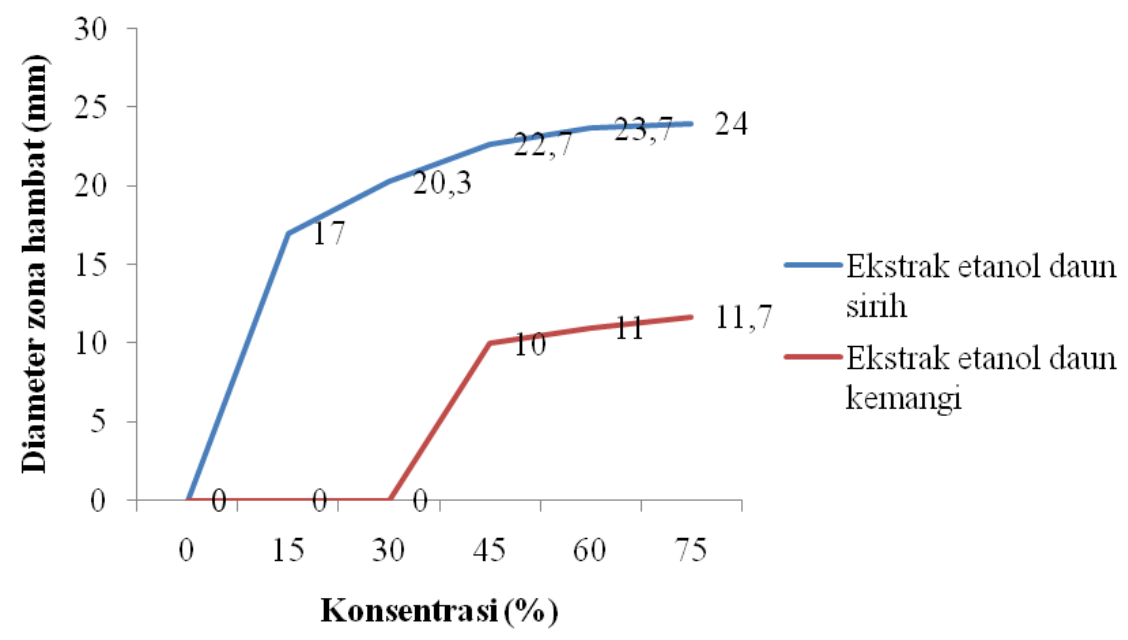

Gambar 1. Grafik uji aktivitas antibakteri ekstrak etanol daun sirih dan ekstrak etanol daun kemangi terhadap S. aureus 
atau pelarut polar lainnya menghasilkan senyawa flavonoid dan tanin. Mekanisme kerja flavonoid sebagai antibakteri adalah membentuk senyawa kompleks dengan protein ekstraseluler dan terlarut sehingga dapat merusak membrane sel bakteri dan diikuti dengan keluarnya senyawa intraseluler, sedangkan tanin sebagai antibakteri adalah menghambat enzim reverse transkriptase dan DNA topoisomerase sehingga sel bakteri tidak dapat terbentuk. Selain faktor senyawa metabolit yang terkandung konsentrasi yang tinggi mempengaruhi besarnya diameter zona hambatan karena banyaknya komponen bioaktif yang terdapat dalam ekstrak $(17,18)$.

$$
\text { Gambar } 2 \text { memperlihatkan }
$$

aktivitas antibakteri kombinasi ekstrak etanol daun sirih dan ekstrak etanol daun kemangi terhadap $S$. aureus. Penggabungan dari kedua ekstrak menghasilkan peningkatan zona hambat yang signifikan. Hal ini kemungkinan karena senyawa-senyawa aktif pada

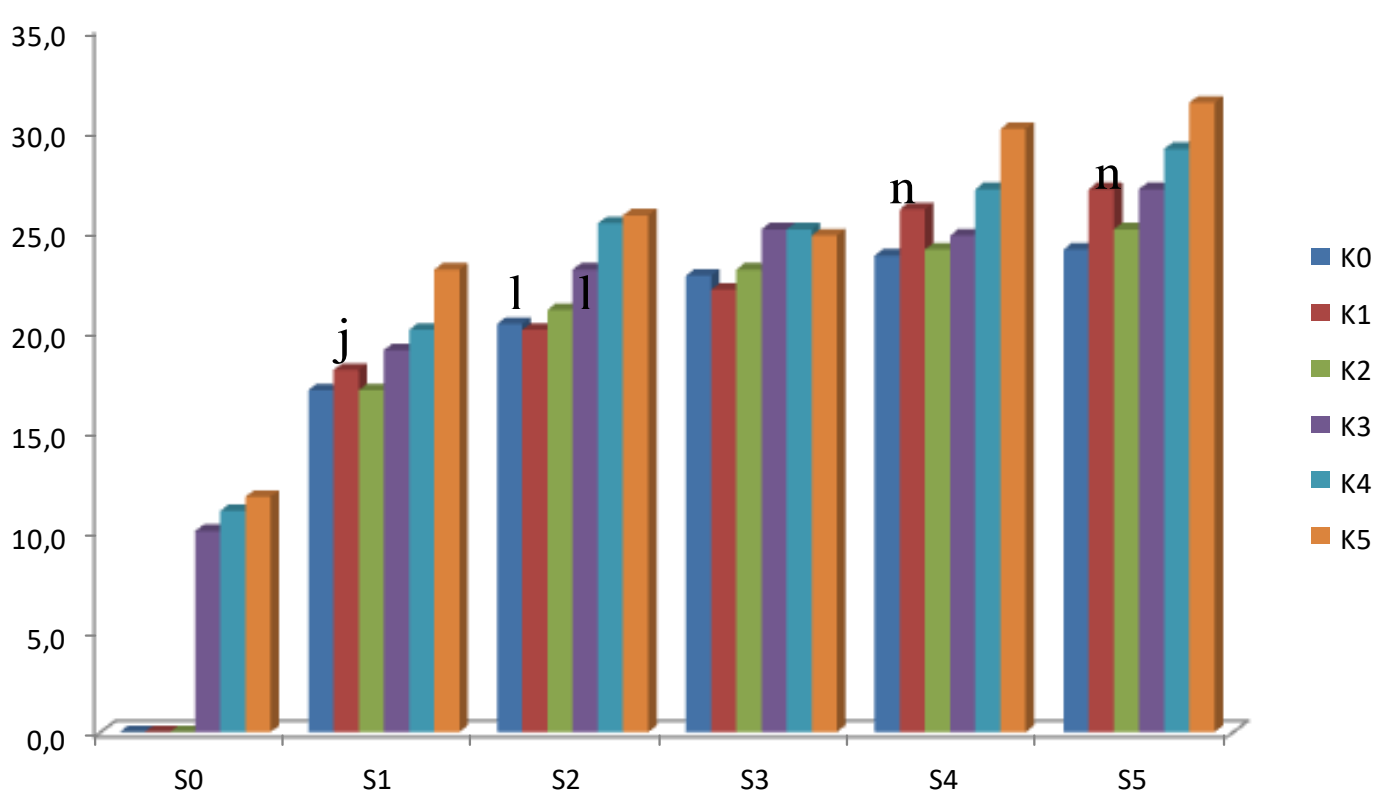

Gambar 2. Grafik uji aktivitas antibakteri kombinasi ekstrak etanol daun sirih dan ekstrak etanol daun kemangi terhadap S. aureus

Keterangan: Huruf yang berbeda pada diagram batang menunjukkan perbedaan signifikan $(\mathrm{p}<$ $0.05)$

S0/K0 = Tanpa ekstrak etanol sirih/kemangi

$\mathrm{S} 1 / \mathrm{K} 1=$ Ekstrak etanol sirih/kemangi konsentrasi $15 \%$

$\mathrm{S} 2 / \mathrm{K} 2$ = Ekstrak etanol sirih/kemangi konsentrasi $30 \%$
$\mathrm{S} 3 / \mathrm{K} 3=$ Ekstrak etanol sirih/kemangi kc $\mathrm{S} 4 / \mathrm{K} 4$ = Ekstrak etanol sirih/kemangi kc S5/K5 = Ekstrak etanol sirih/kemangi kc 
kedua ekstrak bekerja sinergis dalam merusak fungsional bakteri.

Uji statistik dilakukan terhadap uji aktivitas antibakteri ekstrak etanol daun sirih, ekstrak etanol daun kemangi, serta kombinasi ekstrak etanol daun sirih dan ekstrak etanol daun kemangi dengan ANOVA diketahui nilai $\mathrm{p}$ $0,0001<0,05$ artinya perbedaan konsentrasi ekstrak etanol daun sirih dan ekstrak etanol daun kemangi mempengaruhi aktvitas antibakteri pada taraf nyata 5\%. Hasil uji lanjut Duncan menunjukkan bahwa semakin tinggi konsentrasi ekstrak etanol daun sirih, ekstrak etanol daun kemangi, serta kombinasi ekstrak etanol daun sirih dan ekstrak etanol daun kemangi maka semakin besar zona hambat yang terbentuk. Zona hambat terkecil pada ekstrak etanol daun sirih dan ekstrak etanol daun kemangi konsentrasi 0\% (S0 dan K0) dan tertinggi pada konsentrasi $75 \%$ (S5 dan K5). Sedangkan zona hambat terkecil untuk kombinasi ekstrak etanol daun sirih dan ekstrak etanol daun kemangi konsentrasi S0K0, S0K1, dan S0K2 tertinggi pada konsentrasi S5K5, S4K5, dan S5K4.

\section{SIMPULAN}

Berdasarkan hasil penelitian ini dapat disimpulkan, semakin tinggi konsentrasi kombinasi ekstrak etanol daun sirih dan ekstrak etanol daun kemangi maka daya hambat terhadap bakteri $S$. aureus semakin besar. Zona hambat terbesar pada konsentrasi kombinasi ekstrak etanol daun sirih $75 \%$ dan ekstrak etanol daun kemangi $75 \%$

\section{DAFTAR PUSTAKA}

1. Otieno, J.N., Kennedy M.M.H., Herbert V.L., dan Rogasian L.A.M. Multi Plant or Single Plant Extracts, Which Is The Most Effective for Local Healing in Tanzania. Afr.J.Trad CAM. 2008; 5(2):165-172.

2. Ginanjar, E.F., Retnaningrum, E. Septriani, N.I. Octaviani, A. Wiyati, D.A.T.M., dan Rosrinda, E. Handy gel Carrota Hasil Fermentasi Daun wortel Sebagai Antibakteri Penyebab Penyakit kulit, Seminar Nasional Biologi. Fakultas Biologi Universitas Gadjah Mada. Yogyakarta, 2010:1169.

3. WHO. Initiative for Vaccine Research (IVR), Staphylococcal infection. 2013. (http://www.who.int/vaccine_resear ch/disease/soa_bacterial/en/index2. htm 1 diakses tanggal 2 Maret 2017).

4. Dobson, R.G. Handwashing Programed could be Intervention of Choice for Diarrhoeal Diseases, BMJ. 2003; 326: 004.

5. Rachmawati, F.J dan S.Y. Triyana. Perbandingan Angka Kuman pada Cuci Tangan dengan Beberapa 
Bahan sebagai Standarisasi Kerja di Laboratorium Mikrobiologi

Fakultas Kedokteran Universitas Islam Indonesia. Jurnal Logika. 2008; 5(1):1-13.

6. Suliantari, B.S.L. Jenie, M.T. Suhartono dan A. Apriantono. Aktivitas Antibakteri Ekstrak Daun Sirih Hijau (Piper betle L.) terhadap Bakteri Patogen Pangan. Jurnal Teknologi dan Industri Pangan. 2008; 19(1):1-7.

7. Kursia, S., J.S. Lebang. B. Taebe, A. Burhan, W.O.R. Rahim dan Nursamsiar. Uji Aktivitas Antibakteri Ekstrak Etilasetat Daun Sirih Hijau (Piper betle L.) terhadap bakteri Staphylococcus epidermidis. IJPST. 2016; 2(2):72-77.

8. Effa dan N.R. Puetri. Pengaruh Pemberian Ekstrak Daun Sirih (Piper betle L.) terhadap Pertumbuhan Staphylococcus aureus Isolat dari Penderita Faringitis. SEL. 2015; 2(2): 5765.

9. Telci, I., E. Bayram, G. Yilmaz and B. Avci. Variability in Essential oil composition of Turkish Basils (Ocimum basilicum L.). Biochemical Systemic Ecology. 2006; 34:486-491.

10. Angelina, M., M. Turnip dan S. Khotimah. Uji Aktivitas Antibakteri Ekstrak Etanol Daun Kemangi (Ocimum sanctum L.) terhadap Pertumbuhan Bakteri Escherichia coli dan Staphylococcus aureus. Protobiont. 2015; 4(1): 184-189.

11. Siswandono dan Soekardjo, B. Kimia Medisinal. Surabaya:
Airlangga University Press. 2000. P.10-14.

12. Rachmawati. Interaksi Ekstrak Daun Lidah Buaya (Aloe vera L.) dan Daun Sirih (Piper betle L.) terhadap Daya Hambat Staphylococcus aureus secara In Vitro. Jurnal EduBio Tropika 2014; 2(1): 121-127.

13. Hanlon, A., M. Taylor and J.D. Dick. Agar Dilution Susceptibility Testing. Dalam: Schwalbe, R., L. Steele-Moore \& A.C. Goodwin (Eds.). 2007. Antimicrobial susceptibility Testing Protocols. CRC Press, London. 2007. p. 91104.

14. Saifudin, A., Rahayu, dan Teruna. Standarisasi Bahan Obat Alam. Graha Ilmu: Yogyakarta. 2011

15. Valgas C, de Souza SM, Smania EFA, SmaniaJr A. Screening Methods to Determine Antibacterial Activity of Natural Products. BJM. 2007; 38:369380.

16. Harbourne, J.B. Metode Fitokimia, Penuntun Cara Modern Menganalisis Tumbuhan. Bandung Penerbit, ITB. 1987. p. 6-7.

17. Brooks, G.F., J.S. Butel, S.A. Morse. Mikrobiologi Kedokteran Jawetz. Alih bahasa: Huriawati $\mathrm{H}$. Edisi ke 23. EGC. Jakarta. 2007.

18. Nuria, M.C., A. Faizatun., dan Sumantri. 2009. Uji Antibakteri Ekstrak Etanol Daun Jarak Pagar (Jatropha cuircas L) terhadap Bakteri Staphylococcus aureus ATCC 25923, Escherichia coli ATCC 25922, dan Salmonella typhi ATCC 1408. Jurnal Ilmu -Ilmu Pertanian. 5: $26-37$ ). 